\title{
Application of the Red List Index as an indicator of habitat change
}

\author{
Juslen, Aino Kaisa
}

2016-03

Juslen, A K, Pykälä, J , Kuusela , S , Kaila , L J , Kullberg , J B , Mattila , J A, Muona , J E , Saari , S E \& Cardoso , P 2016, ' Application of the Red List Index as an indicator of habitat change ' , Biodiversity and Conservation , vol. 25 , no. 3 , pp. 569-585 . https://doi.org/10.1007/s10531-016-1

http://hdl.handle.net/10138/173992

https://doi.org/10.1007/s10531-016-1075-0

acceptedVersion

Downloaded from Helda, University of Helsinki institutional repository.

This is an electronic reprint of the original article.

This reprint may differ from the original in pagination and typographic detail.

Please cite the original version. 
1 Application of the Red List Index as an indicator of habitat change

2 Aino Juslén ${ }^{a^{*}}$, Juha Pykäläb, Saija Kuusela ${ }^{b}$, Lauri Kailaa, Jaakko Kullberga , Jaakko Mattila ${ }^{a}$, Jyrki Muona ${ }^{a}$,

3 Sanna Saaria ${ }^{2}$ Pedro Cardoso ${ }^{a}$.

4 a Finnish Museum of Natural History, University of Helsinki, P.O. Box 17, FI-00014 University of Helsinki

$5 \quad$ b Finnish Environment Institute, P.O. Box 140, FI-00251 Helsinki

6 Corresponding author:

7 Aino Juslén: aino.juslen@helsinki.fi; tel. +358 50 3109703, Finnish Museum of Natural History, University of Helsinki, $8 \quad$ P.O. Box 17, FI-00014 University of Helsinki

\section{Abstract}

12 For the first time ever, the International Union for Conservation of Nature Red List Index for habitat types

13 was calculated for an entire country, Finland. The RLIs were based on species threat assessments from

142000 and 2010 and included habitat definitions for all 10131 species of 12 organism groups. The RLIs

15 were bootstrapped to track statistically significant changes. The RLI changes of species grouped by

16 habitats were negative for all habitat types except for forests and rural biotopes which showed a stable

17 trend. Trends of beetles and true bugs were positive in rural and forest habitats. Other 16 observed trends

18 of species group and habitat combinations were negative. Several trends observed were in accordance

19 with studies focusing on particular taxa and habitats, and drivers for their change. This study demonstrates

20 the usefulness of the RLI as a tool for observing habitat change based on species threat assessment data.

21 Keywords: biodiversity indicator, biodiversity loss, habitat, Finland, RLI, threatened species 
25 The 2010 conference of the parties to the Convention on Biological Diversity (CBD) in Aichi, Japan declared the 20102020 decade as a Decade on Biodiversity. Twenty biodiversity targets were set to be met by the year 2020 (Tittensor et al. 2014). By 2020 the extinction of known threatened species has been prevented and their conservation status, particularly of those most in decline, has been improved and sustained. The IUCN Red List of Threatened Species is the most widely used information source on the extinction risk of species (Rodrigues et al. 2006; Mace et al. 2008; but see Cardoso et al. 2011, 2012). The IUCN Red List Index (RLI) (Butchart et al. 2004, 2007), which reflects overall changes in IUCN Red List status over time of a group of taxa, was agreed by the parties to the CBD to be used as an overall index of change, to quantify to what extent target 12 is being met.

The RLI uses weight scores based on the Red List status of each of the assessed species. These scores range from 0 (Least Concern) to Extinct/Extinct in the Wild (5). Summing these scores across all species and relating them to the worst-case scenario - all species extinct - gives us an indication of how biodiversity is doing. Importantly, the RLI is based on true improvements or deteriorations in the status of species, i.e.

2007).The RLI approach helps to develop a better understanding of which taxa, regions or ecosystems are declining or improving. The aim is to provide policy makers, stakeholders, conservation practitioners and the general public with sound knowledge of biodiversity status and change, and tools with which to make informed decisions.

At a global level, the IUCN Red List Index has been calculated for birds (Butchart et al. 2004; Hoffman et al. 2010), mammals (Hoffmann et al. 2010, 2011), amphibians (Hoffman et al. 2010), corals (Butchart et al. 2010), and cycads (The Millenium Development Goals Report 2015). An ongoing project is heading to present a sampled Red List Index (SRLI, Baillie et al. 2008) of plants (Brummitt et al. 2015) and efforts towards a SRLI of butterflies (Lewis and Senior 2011) and Odonata are made (Clausnitzer et al. 2009). At a regional and national level, RLIs or SRLIs have been presented for certain groups (Lopez et al. 2011; Szabo et al. 2012; Moreno Saiz et al. 2015; Woinarski et al. 2015) or multiple species groups (Gärdenfors 2010; Juslén et al. 2013; Rondinini et al. 2014).

A parallel set of criteria was proposed to be applied to ecosystems in lieu of species, with much the same objectives, the IUCN Red List of Ecosystems (RLE, Rodríguez et al. 2011). This has not been widely 
53 adopted as of yet, either at global or regional scales. National assessments of threatened habitat types 54 have been carried out, for example in Finland (Raunio et al. 2008; Kontula and Raunio 2009). Kontula and 55 Raunio (2009) even presented a procedure for assigning IUCN Red List categories for habitat types.

56 However, this assessment has been carried out only once in Finland, and temporal trends cannot be 57 presented as of yet.Until repeated assessments of risk of collapse of particular ecosystem types are 58 available using the Red List of Ecosystems approach, it will not be possible to produce a Red List Index for 59 different ecosystems using the RLE approach. However, as a proxy for ecosystem or habitat change, it is 60 possible to calculate RLIs for sets of species characteristic of particular ecosystem or habitat types.

61 Butchart et al. (2004) has already used such an approach for birds. In practice, any index based on species

Here we propose and develop the first national RLI applied to ecosystem level, using Finnish species and their habitats as an example. The approach is intended to complement both the taxon-based RLI and the ecosystem-based RLE, bridging the gap between the two.

\section{Material and methods}

\subsection{Species data}

There are approximately 45000 known species in Finland, and about 21400 of these had adequate data for threat assessments both in 2000 and 2010 (Rassi et al. 2001, 2010). The present study is based on 10 131 taxa assessed in both years, (Table 1), as we restricted the analyses to species groups well covered in both assessments: beetles (3 384 species), butterflies \& moths (below denoted as butterflies) (2 247), 
79 lichens (1 392), vascular plants (1 197), bryophytes (873), true bugs (463), birds (237), polypores (220), 80 mammals (57), dragonflies and damselflies (51) and herptiles (10).

81 As a part of the method, back casting was used to identify the species with genuine threat category changes. The 2000 Red List categories were adjusted retrospectively based on current information and taxonomy when needed. The RLI calculations include only category changes due to genuine changes in species statuses (Butchart et al. 2007). Back casting was performed already for species groups other than Lepidoptera by Juslén et al. (2013). The reasons for any category change are listed in Rassi et al. 2010 for the species in threatened categories regionally extinct (RE), critically endangered (CR), endangered (EN), vulnerable (VU), near-threatened (NT) and data deficient (DD). The working documentation lists reasons for the Least Concern (LC) species. Any challenging back casting cases were separately discussed with experts of the group in question. Regarding Lepidoptera, LK and JK have made the back casting purposely for the study now presented. Altogether 529 genuine changes were found in the 12 groups studied (Table 1).

\subsection{Habitat data}

The habitats for species listed in the Finnish Red Data Book (i.e. for those categorized as RE, CR, EN, VU, and NT) were published by Rassi et al. (2010). For LC species we followed the unpublished habitat classification listed at the threat assessment documentation or other working documentation produced by expert groups during two years (except beetles and butterflies, for which no classification was produced previously).

The habitat classification categories were: forests, mires, aquatic habitats, shores, rock outcrops (including erratic boulders), alpine heaths and meadows above tree-level, and rural biotopes and cultural habitats. Definitions of the habitats are given in table 2, and more detailed subcategorizations are published in Rassi et al. 2010. These differ from the standard classifications by IUCN (http://www.iucnredlist.org/technicaldocuments/classification-schemes/habitats-classification-scheme-ver3) in two ways (see also Tables 2 and 5). First, mires were separated from other aquatic habitats due to their exceptional extension in Finland and importance for many Finnish species. Second, marine intertidal and coastal areas were merged due to the difficulty in separating them given the characteristics of Finnish geology and marine hydrology. 
The habitat classification for Least Concern beetles and butterflies was conducted in this study. Habitats of the Least Concern species of Coleoptera were based on published sources (Koch 1989a, 1989b, 1992) and checked by Jaakko Mattila and Jyrki Muona. Besides own expertise, we used a database consisting of 670000 observations of beetles in Finland. This database is not public, but the Finnish Coleoptera Atlas based on the database has been published (The Finnish Expert Group on Coleoptera 2010). The habitats of the least concern species of Lepidoptera were defined by experts Lauri Kaila and Jaakko Kullberg, who also had a database of Lepidoptera of 1.600000 observations supporting their work (Hyönteistietokanta).

Additionally, a few missing habitats for the other ten groups of organisms were obtained with the help of the Finnish expert groups of species. The whole habitat classification data per species is given in Appendix 1.

Often species occur and establish sustaining populations on several habitat types. Yet, one habitat could always be pointed out by experts as the primary habitat type. This might be the original habitat of the species, for instance, Thymus serpyllum is classified to forests, as its original main habitat in Finland is esker forests (Hämet-Ahti et al. 1998), although it nowadays also occurs on sandy riverbanks and sometimes on sandy road banks. Or it might be the habitat where the species occurs in higher abundance. For high-mobility animals, that may occur in different habitats seasonally or during their life cycles, e.g. birds, the primary habitat was the preferential nesting habitat. Habitats of holomethabolic insects were defined according to the larvae preference, as most of their life-cycle is spent on this stage.

\subsection{The Red List Index for habitats}

Based on the red-list status of species occupying each habitat, we calculated the RLI for habitats.

The RLI value was calculated by multiplying the number of taxa in each red-list category by the category weight ( 0 for LC, 1 for NT, 2 for VU, 3 for EN, 4 for CR, 5 for RE/EX). These products were summed and then divided by the number of taxa multiplied by the maximum weight $5 \ddagger P D[L P X P S R V V L E O H G H Q R P L Q D W R U$. To obtain the RLI value, this sum is subtracted from 1. The index value varies between 0 and 1 (Butchart et al. 2007). The lower the value, the closer the set of taxa is heading towards extinction. If the value is 0 all the taxa are (regionally) extinct. If the value is 1 all the taxa are assessed as Least Concern. The 
instructions for national and regional use by Bubb et al. (2009) exclude the species that have been assessed as Extinct (EX) in the earlier assessment. We calculated the RLIs including the taxa assessed as Regionally Extinct (RE) in 2000, as some of these taxa were rediscovered in Finland during the observed period (see also Juslén et al. 2013).

\subsection{Statistical analysis}

We conducted independent analyses with different species groupings by taxon, by habitat and a combination of these. For each group of species in the three groupings we calculated three values: RLI 2000, RLI 2010 and the change between the years (i.e. RLI 2010 - RLI 2000). A simple arithmetic analysis would not show whether the group indices were statistically different or the change between the years was significantly different from a null hypothesis of no change. We therefore resampled all the values with nonparametric bootstrapping. For each group, species were randomly sampled with replacement until the original number of species was attained. For each of the 10.000 resampling events the RLI 2000, RLI 2010 and the respective differences ZHUHFDOFXODWHG7KHFRQILGHQFHOLPLWV. RIWKH5/,YDOXHVSHUJURXS and year were the 2.5 and 97.5 percentiles of the respective 10.000 randomizations. The change between the years was considered statistically significant if more than $95 \%$ of the randomization values had the same sign (either increase or decrease) as the true values. Statistics were performed using the R 3.1.2 statistical environment (R Core Team 2014).

\section{Results}

The number of taxa in different primary habitats was 4031 in forests, 513 in mires, 633 in aquatic habitats, 1257 in shores, 969 in rock outcrops, 411 in alpine heaths and meadows, and 2317 in rural biotopes (Table 3).

The RLI value for all Finnish species combined was 0.882 in 2000 and 0.879 in 2010. The minor changes observed against Juslén et al. (2013) were due to the inclusion of Lepidoptera in the dataset. The new bootstrap analyses showed that dragonflies, true bugs and beetles were statistically less threatened than the other groups, whose confidence limits mostly overlap (Fig. 1). The RLI changes between the years 
were significantly negative for bryophytes, lichens, vascular plants, butterflies and birds and positive for beetles and true bugs (Table 4). Dragonflies, herptiles, mammals and polypores show no significant trend.

Alpine habitats followed by rock outcrops present the most threatened species on average, with aquatic habitats, forests and mires hosting the least threatened (Fig. 2). The RLI changes between the years were significantly negative for all habitat types except forests and rural biotopes, which show no significant trends (Table 5).

Significant RLI trends between 2000 and 2010 were found for 20 combinations of groups of organisms with primary habitats (Table 6; Appendix 2). The trends of beetles and true bugs were positive in rural and forest habitats, otherwise observed trends were all negative. Trends of bryophytes were negative in six habitats and of vascular plants in five. Negative trends were also recovered in two habitats for both birds and lichens, and in one habitat for butterflies. In dragonflies and damselflies, polypores, herptiles and mammals no positive or negative trends were observed (Appendix 2).

\section{Discussion}

This study demonstrates that it is useful to calculate the RLI for species grouped by habitat, in addition to the usual taxonomic grouping. Several trends were revealed in accordance with published studies focusing on particular taxa and habitats. In general, more negative trends were found, with positive trends being possibly due to the effects of climate warming on several insect species that are expanding northwards. Few scientific papers analyzing reasons for population changes among the Finnish threatened species other than birds exist. Only in one habitat type (forests) several papers focused on recent trends in threatened species were available, such as the simulation study by Fedrowitz et al. (2012) showing continuous decrease of threatened epiphytic lichens. Our main findings, grouped by habitats, are elaborated in the table 5 with likely drivers and references with supporting notes.

We suggest that the habitat-based RLI may show a different, complementary view to the ecosystem-based RLE. Even though some habitats may not be improving, their constituent species may show positive trends 
due to other factors such as the climate change. The habitat-based RLI clearly bridges the gap between the taxon-based RLI and the RLE.

The RLI has been used in multiple ways, usually to evaluate the impact of contrasting policies on the threat status of different taxonomic groups. Hoffmann et al. (2011) used it to attempt to quantify the impact of conservation efforts on the extinction risk of two groups of mammals. Young et al. (2014) quantified the impact of a conservation organisation's programmes on extinction risk of a set of species. Visconti et al. (2015) used the RLI for projecting the likely impact of different policy decisions. Moreno Saiz et al. (2015) tested it as a tool to assess the success of national conservation policies.

The latter authors recommended using various indicators as basis for planning regional conservation measures and evaluating their success. However, they also listed several challenges in using and interpreting the RLI. Above all, they recognize it is a summary statistic, which may mask the individual patterns under a global trend. For example, if 10 species increase and 10 decrease in their status the index will reveal the exact same value as if no species change at all, although these are quite different situations. Researchers and stakeholders should therefore always search for individual species that may be at odds with the general trend of the group and try to understand why this might happen. Although this is also verified in the present study, our results show the RLI to be useful for evaluating species trends in different habitat types.

As mentioned, besides the RLI other indices can be disaggregated into different groups so that different aspects of biodiversity change can be studied. These might be taxonomic groups (the subject of most RLI studies), habitat types (the subject of this study), or many other. Dividing species into functional groups may be a particularly useful way of using the RLI, as function is related with ecosystem services and thus trends in particular groups may reveal or even precede changes in services, many of them critical for human well-being. 


\section{References}

Albrecht A, Mattila K, Rinne V, Rintala T, Söderman G (2010) Hemiptera. In: Rassi P, Hyvärinen E, Juslén A, Mannerkoski I. (eds) The 2010 red list of Finnish species. Ympäristöministeriö and Suomen ympäristökeskus, Helsinki, pp 397-416

Baillie JEM, Collen B, Amin R, Akçakaya HR, Butchart SHM, Brummitt NA, Meagher TR, Ram M, HiltonTaylor C, Mace GM (2008) Toward monitoring global biodiversity. Conservation Letters 1: 18-26

Brommer J, Lehikoinen A, Valkama J (2012) The Breeding Ranges of Central European and Arctic Bird Species Move Poleward. PloS One (Article: e43648). DOI: 10.1371/journal.pone.0043648

Brummitt N, Bachman SP, Aletrari E, Chadburn H, Griffiths-Lee J, Lutz M, Moat J, Rivers MC, Syfert MM, Nic Lughadha EM (2015) The sampled red list index for plants, phase II: ground-truthing specimen-based conservation assessments. Philos T Roy Soc B 370 (Article: 20140015). DOI: 10.1098/rstb.2014.0015

Bubb PJ, Butchart SHM, Collen B, Dublin H, Kapos V, Pollock C, Stuart SN, Vié JC (2009) IUCN Red List indext guidance for national and regional use. IUCN, Gland

Butchart SHM, Stattersfield AJ, Bennun LA, Shutes SM, Akçakaya HR, Baillie JEM, Stuart SN, HiltonTaylor C, Mace GM (2004) easuring global trends in the status of biodiversity: Red List Indices for birds. PLOS Biology (Article: e383). DOI:10.1371/journal.pbio.0020383

Butchart SHM, Akçakaya HR, Chanson J, Baillie JEM, Collen B, Quader S, Turner WR, Amin R, Stuart SN, Hilton-Taylor C (2007) Improvements to the Red List index. PLOS One (Article: e140). DOI:

10.1371/journal.pone. 0000140 .

Butchart SHM et al (2010) Global biodiversity: indicators of recent declines. Science 328: 1164-1168 
246 Cardoso P, Borges PAV, Triantis KA, Ferrández MA, Martín JL (2011) Adapting the IUCN Red List criteria 247 for invertebrates. Biol Conserv 144: 2432-2440

Cardoso P, Borges PAV, Triantis KA, Ferrández MA, Martín JL (2012) The underrepresentation and misrepresentation of invertebrates in the IUCN Red List. Biol Conserv 149: 147-148

Clausnitzer V et al. (2009) Odonata enter the biodiversity crisis debate: The first global assessment of an insect group. Biol Conserv 142: 1864-1869

Collen B, Loh J, McRae L, Whitmee S, Amin R, Baillie JEM (2009) Monitoring change in vertebrate abundance: the Living Planet Index. Conservation Biology 23: 317-327

Fedrowitz K, Kuusinen M, Snäll T (2012) Metapopulation dynamics and future persistence of epiphytic cyanolichens in a European boreal forest ecosystem. J Appl Ecol 49: 493-502

The Finnish Expert Group on Coleoptera (2010) The Finnish Expert Group on Coleoptera 2010. Atlas of the Beetles of Finland. http://koivu.luomus.fi/elaintiede/kovakuoriaiset/catlas1.htm.

Gärdenfors U (ed.) (2010) Rödlistade arter i Sverige 2010 - the 2010 red list of Swedish species.

ArtDatabanken, Uppsala

Hanski I (2000) Extinction debt and species credit in boreal forests: modelling the consequences of different approaches to biodiversity conservation. Ann Zool Fenn 37: 271-280

Hanski I (2005) The shrinking world: Ecological consequences of habitat loss. International Ecology Institute, Oldendorf

Hautala H, Laaka-Lindberg S, Vanha-Majamaa I (2011) Effects of retention felling on epixylic species in boreal spruce forests in southern Finland. Restor Ecol 19: 418-429 
Hedenås H, Hedström P (2007) Conservation of epiphytic lichens: Significance of remnant aspen (Populus tremula) trees in clear-cuts. Biol Conserv 135: 388-395

Hoffman M et al. (2010) 7KHLPSDFWRIFRQVHUYDWLRQRQWKHVWDWXVRIWKHZRUOGףVYHßBVHEUDWH $1503-1509$

Hoffman M, Belant JL, Chanson JS, Cox NA, Lamoreux J, Rodrigues ASL, Schipper J, Stuart SN (2011) 7KHFKDQJLQJIDWHVRIWKHZRUOGTVPDPIRIDOV Roy Soc B 366: 2598-2610

Hyvärinen E, Kouki J, Martikainen P (2006) Fire and green-tree retention in conservation of red-listed and rare deadwood-dependent beetles in Finnish boreal forests. Conserv Biol 20: 1710-1719

Hyönteistietokanta (http://hyonteiset.luomus.fi/insects/main/EntDatabase.html) [Entomological database]. Finnish Museum of Natural History, Helsinki, 27.10.2015

Hämet-Ahti L, Suominen J, Ulvinen T, Uotila P (eds.) (1998) Retkeilykasvio, 4. uudistettu painos, Luonnontieteellisen keskusmuseon kasvimuseo, Helsinki.

Ikonen I (2011) Integrated coastal planning and management in southwest Finland. In: Reihmanis J (ed.) Nordic-Baltic-Belarus solutions in farming for biodiversity. Latvijas Dabas Fonds, Riga, pp 34-41

Ilmonen J, Mykrä H, Virtanen R, Paasivirta L, Muotka T (2012) Responses of spring macroinvertebrate and bryophyte communities to habitat modification: community composition, species richness, and red-listed species. Freshwater Science 31: 657-667 
303 Johansson P (2008) Consequences of disturbance on epiphytic lichens in boreal and near boreal forests.

304 Biol Conserv 141: 1933-1944

305

306

307

308

309

310

311

312

313

314

315

316

317

318

319

320

32

322

323

324

325

326

327

328

329

Juslén A, Hyvärinen E, Virtanen LK (2013) Application of the Red-List Index at a national level for multiple species groups. Conserv Biol 27: 398-406

Jutila $H$ (2001) How does grazing by cattle modify the vegetation of coastal grasslands along the Baltic Sea? Ann Bot Fenn 38: 181-200

Koch K (1989a) Die Käfer Mitteleuropas. Ökologie. Band 1. Krefeld, Goecke \& Evers

Koch K (1989b) Die Käfer Mitteleuropas. Ökologie. Band 2. Krefeld, Goecke \& Evers

Koch K (1992) Die Käfer Mitteleuropas. Ökologie. Band 3. Krefeld, Goecke \& Evers

Kontula T, Raunio A (2009) New method and criteria for national assessments of threatened habitat types.

Biodivers Conserv 18: 3861-3876

Kouki J, Arnold K, Martikainen P (2004) Long-term persistence of aspen - a key host for many threatened species - is endangered in old-growth conservation areas in Finland. J Nat Conserv 12: 41-52

Laaksonen T, Lehikoinen A (2013) Population trends in boreal birds: Continuing declines in agricultural, northern, and long-distance migrant species. Biol Conserv 168: 99-107

Lewis OT, Senior MJM (2011) \$VVHVVLQJFRQVHUYDWLRQVWDWXVDQGWUHQGVIRUWKHZRUOGTVEXW Sampled Red List Index approach. J Insect Conserv 15: 121-128 
330 Loh J, Green RE, Ricketts T, Lamoreux JF, Jenkins M, et al. (2005) The Living Planet Index: using species 331 population time series to track trends in biodiversity. Philosophical Transactions of the Royal Society of 332 London B, 360: 289-295

Lopez L (2011) Estado de las Aves del Paraguay. Guyra Paraguay, BirdLife International. Asunción, Paraguay.

Mace GM, Collar NJ, Gaston KJ, Hilton-Taylor C, Akçakaya HR, Leader-Williams N, Milner-Gulland EJ, Stuart SN (2008) 4XDQWLILFDWLRQRIH[WLQFWLRQULVN,8\&19VVIVWHPIRUFODVVLIILQJWKUHDWHQHG Conserv Biol 22: 1424-1442

Martikainen P (2001) Conservation of threatened saproxylic beetles: significance of retained aspen Populus tremula on clearcut areas. Ecol Bull 49: 205-218

The Millenium Development Goals Report 2015. United Nations, New York.

Moreno Saiz JC, Domínguez Lozano F, Marrero Gómez M, Bañares Baudet Á (2015) Application of the

Red List Index for conservation assessment of Spanish vascular plants. Conserv Biol 29: 910-919

Olofsson J, Oksanen L (2005) Effects of reindeer density on vascular plant diversity on North Scandinavian mountains. Rangifer 25: 5-18

Penttilä R, Siitonen J, Kuusinen M (2004) Polypore diversity in a managed and old-growth boreal Picea abies forests in southern Finland. Biol Conserv 117: 271-273

Pykälä J (2000) Mitigating human effects on European biodiversity through traditional animal husbandry. Conserv Biol 14: 705-712 
360 Pöyry J, Luoto M, Heikkinen RK, Kuussaari M, Saarinen K (2009) Species traits explain recent range shifts

361 of Finnish butterflies. Glob Change Biol 15: 732-743

363 Pöysä H, Rintala J, Lehikoinen A, Väisänen, R.A., 2012. The importance of hunting pressure, habitat 364 preference and life history for populations trends of breeding waterbirds in Finland. Eur J Wildlife Res 59: 245-256

Raatikainen KM, Heikkinen RK, Pykälä J (2007) Impacts of local and regional factors on vegetation of boreal semi-natural grasslands. Plant Ecol 189: 155-173

Rassi P, Alanen A, Kanerva T, Mannerkoski I (eds) (2001) Suomen lajien uhanalaisuus 2000.

Ympäristöministeriö \& Suomen ympäristökeskus, Helsinki

Rassi P, Hyvärinen E, Juslén A, Mannerkoski I (eds) (2010) Suomen lajien uhanalaisuus† Punainen kirja

2010. The 2010 red list of Finnish species. Ympäristöministeriö ja Suomen ympäristökeskus, Helsinki

R Core Team (2014) R: A language and environment for statistical computing. R Foundation for Statistical Computing, Vienna, Austria. Available at http://www.R-project.org/

Raunio A, Schulman A, Kontula T, (eds) (2008) Assessment of threatened habitat types in Finland - part 1: Results and basis for assessment (in Finnish). Suomen ympäristö 8: 1-264

Reinikainen A, Mäkipää R, Vanha-Majamaa I, Hotanen JP (eds) (2000) Kasvit muuttuvassa metsäluonnossa. Metsäntutkimuslaitos \& Kustannusosakeyhtiö Tammi, Helsinki for conservation. Trends Ecol Evol 21: 71-76 
387 Rodríguez JP et al (2011) Establishing IUCN Red List criteria for threatened ecosystems. Conserv Biol 25: $388 \quad 21-29$

Rondinini, C., Battistoni, A., Teofili, C. 2014. /RVWDWRGHOOD\%LRGLYHUVLWjLQ,WDOLDOףDSSOLFD]LRQH

Sampled Red List e Red List Index

Szabo JK, Butchart SHM, Possingham HP, Garnett ST (2012) Adapting global biodiversity indicators to the national scale: a red list index for Australian birds. Biol Conserv 148: 61-68

Tikkanen OP, Martikainen P, Hyvärinen E, Junninen K, Kouki J (2006) Red-listed boreal forest species of Finland: associations with forest structure, tree species, and decaying wood. Ann Zool Fenn 43: 373-383

Tittensor DP et al. (2014) A mid-term analysis of progress toward international biodiversity targets. Science 346: $241-244$

Toivanen T, Kotiaho JS (2007) Mimicking natural disturbances of boreal forests: the effects of controlled burning and creating dead wood on beetle diversity. Biodivers Conserv 16: 3193-3211

Virkkala R, Korhonen KT, Haapanen R, Aapala K (2000) Protected forests and mires in forest and mire vegetation zones in Finland based on the 8th National Forest Inventory (In Finnish with an English summary). The Finnish Environment 395: 1-49

Virkkala R, Heikkinen RK, Leikola N, Luoto M (2008) Projected large-scale range reductions of northernboreal land bird species due to climate change. Biol Cons 141: 1343-1353

Virkkala R, Rajasärkkä A (2011) Climate change affects populations of northern birds in boreal protected areas. Biological Letters 7: 395-398

Virkkala R, Rajasärkkä A (2012) Preserving species populations in the boreal zone in a changing climate: contrasting trends of bird species groups in a protected area network. Nature Conserv 3: 1-20 
417 Visconti P et al (2015) Projecting global biodiversity indicators under future development scenarios.

418 Conserv Lett DOI: $10.1111 /$ conl.12159

420 Woinarski JCZ, Burbidgec AA, Harrison PL (2015) Ongoing unraveling of a continental fauna: Decline and 421 extinction of Australian mammals since European settlement. PNAS 112: 4531-4540

423 Young RP, Hudson MA, Terry AMR, Jones CG, Lewis RE, Tatayah V, Zuël N, Butchart SHM (2014)

424 Accounting for conservation: Using the IUCN Red List Index to evaluate the impact of a conservation 425 organization. Biol Conserv 180: 84-96

\section{Figure captions}

Figure 1. The RLI trends between 2000 and 2010 showing the confidence limits for RLI values of each group of organisms.

Figure 2. The RLI trends between 2000 and 2010 showing the confidence limits for RLI values of each primary habitat. 


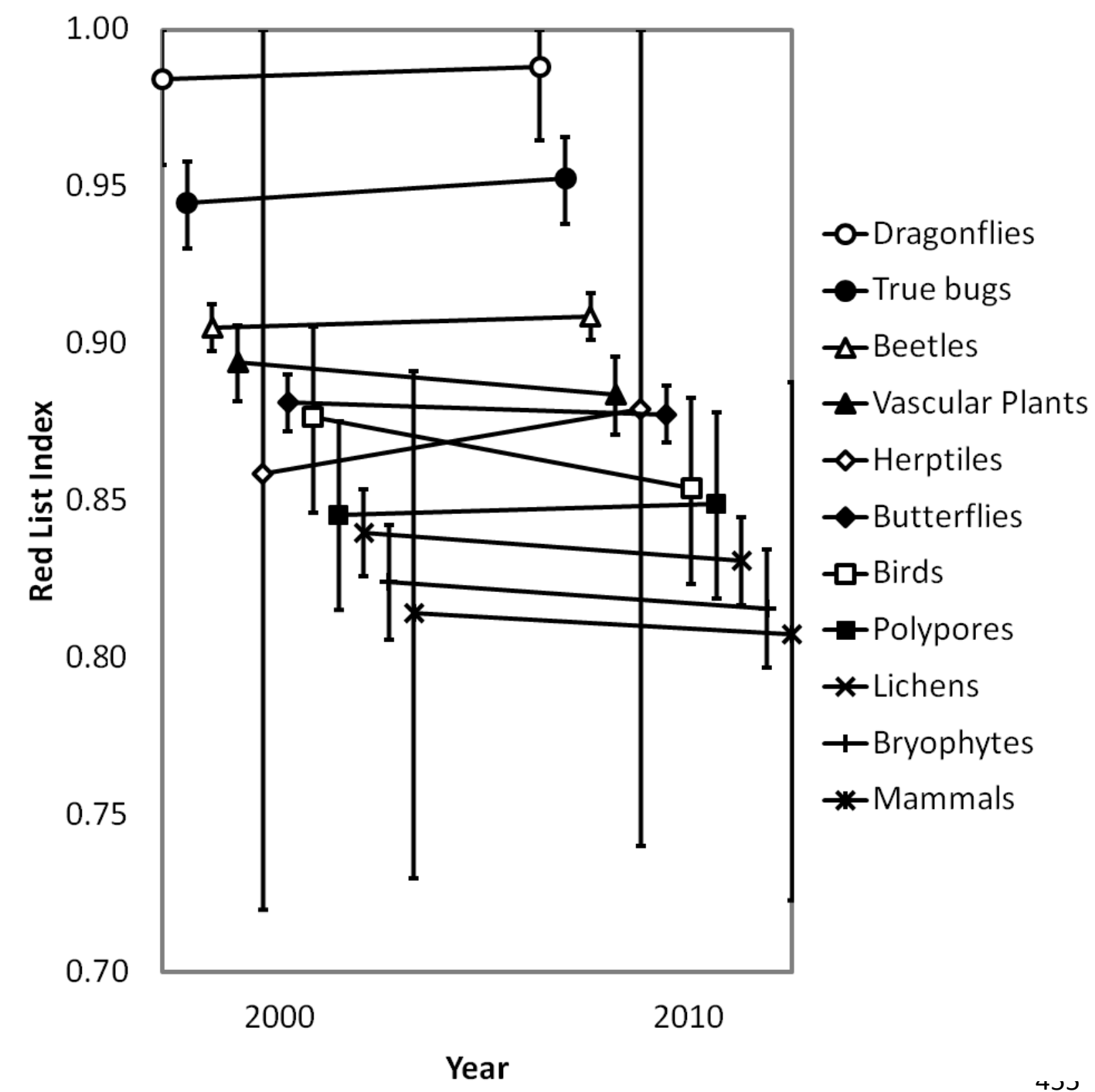

Figure 1. 


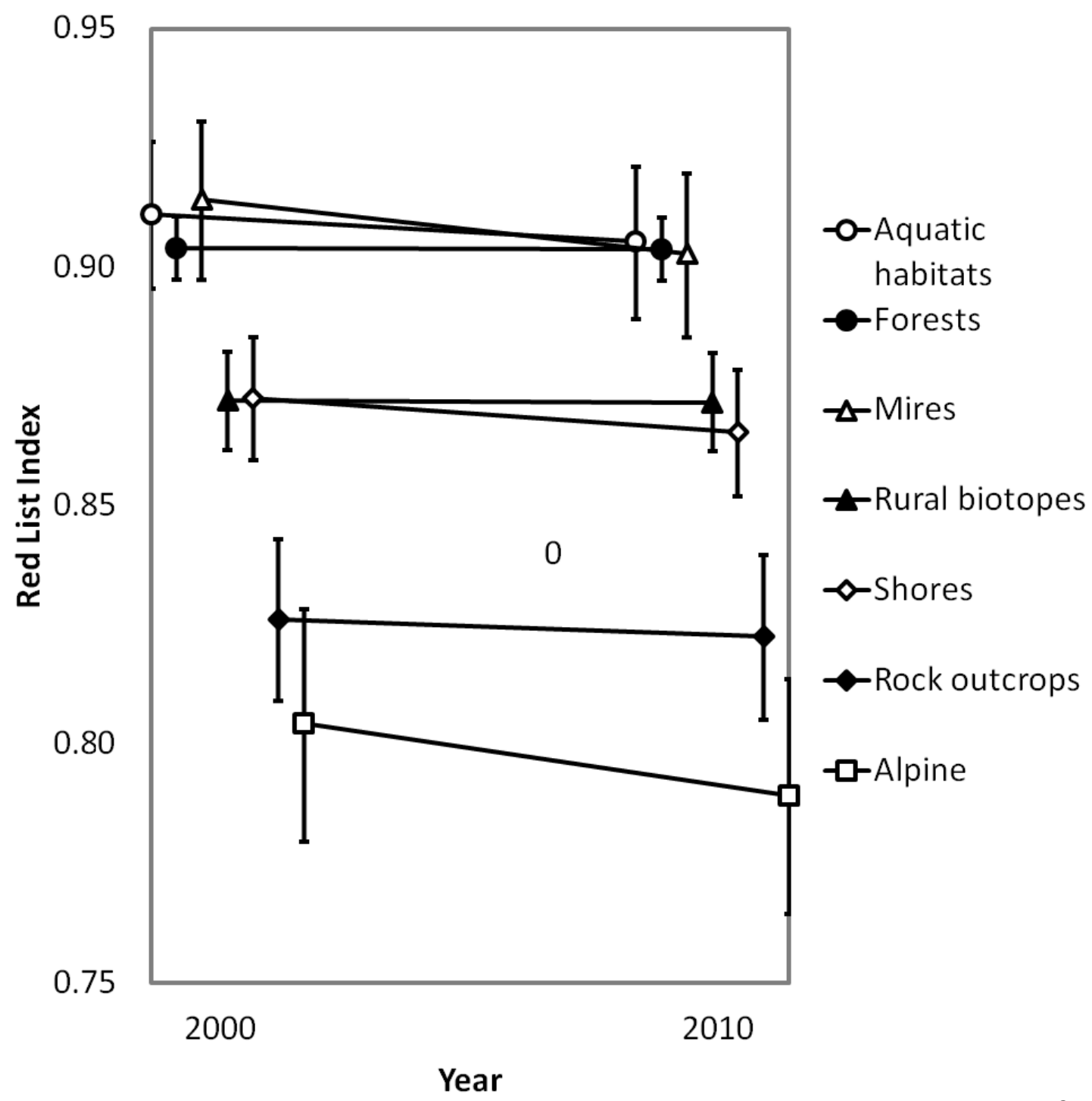

Figure 2. 
Table 1. Number of species known in Finland (Total) by organism groups included in our study, number of taxa included in the red-list assessment of 2010, number of RE, CR, EN, VU, and DD taxa together in 2010, number of taxa excluded from the study because they were Data Deficient or not assessed in 2000 as not having an established population, number of taxa included in the present study and those that genuinely changed red-list category between 2000 and 2010.

\begin{tabular}{|c|c|c|c|c|c|c|}
\hline Organism group & Total & $\begin{array}{l}\text { Assessed } \\
\text { (\% total) }\end{array}$ & $\begin{array}{l}\text { RE, CR, EN, } \\
\text { VU, NT, or } \\
\text { DD (\% } \\
\text { assessed) }\end{array}$ & $\begin{array}{l}\text { Excluded as } \\
\text { Data } \\
\text { Deficient or } \\
\text { other reasons } \\
\text { (\% assessed) }\end{array}$ & $\begin{array}{l}\text { Included } \\
(\% \\
\text { assessed) }\end{array}$ & $\begin{array}{l}\text { Genuinely } \\
\text { changed } \\
\text { (\% } \\
\text { included) }\end{array}$ \\
\hline Beetles (Coleoptera) & 3697 & $\begin{array}{l}3416 \\
(92.4)\end{array}$ & $737(21.6)$ & $32(0.9)$ & $\begin{array}{l}3384 \\
(99.1)\end{array}$ & $138(4.1)$ \\
\hline $\begin{array}{l}\text { Birds (Aves) } \\
\text { Bryophytes (Bryophyta. }\end{array}$ & 249 & $241(96.8)$ & $89(36.9)$ & $4(1.7)$ & 237 (98.3) & $66(27.8)$ \\
\hline $\begin{array}{l}\text { Marchantiophyta and } \\
\text { Anthocerophyta) }\end{array}$ & 906 & 896 (98.9) & $364(40.6)$ & $23(2.6)$ & $873(97.4)$ & $35(4.0)$ \\
\hline Butterflies (Lepidoptera) & 2576 & $\begin{array}{l}2313 \\
(89.8)\end{array}$ & $707(30.6)$ & $66(2.9)$ & $\begin{array}{l}2247 \\
(97.1)\end{array}$ & $130(5.8)$ \\
\hline $\begin{array}{l}\text { Dragonflies and } \\
\text { damselflies (Odonata) }\end{array}$ & 55 & $52(94.5)$ & $1(1.9)$ & $1(1.9)$ & $51(98.1)$ & $1(2.0)$ \\
\hline $\begin{array}{l}\text { Herptiles (Reptilia and } \\
\text { Amphibia) }\end{array}$ & 12 & $10(83.3)$ & $3(30.0)$ & 0 & $10(100)$ & $1(10.0)$ \\
\hline Lichens (Lichenes) & 1832 & $\begin{array}{l}1545 \\
(84.3)\end{array}$ & $686(44.4)$ & $153(9.9)$ & $\begin{array}{l}1392 \\
(90.1)\end{array}$ & $59(4.2)$ \\
\hline $\begin{array}{l}\text { Mammals (Mammalia) } \\
\text { Polypores }\end{array}$ & 72 & 59 (81.9) & $22(37.3)$ & $2(3.4)$ & $57(96.6)$ & $4(7.0)$ \\
\hline $\begin{array}{l}\text { (Aphyllophorales and } \\
\text { Heterobasidiomycetes) }\end{array}$ & 237 & 225 (94.9) & $95(42.2)$ & $5(2.2)$ & $220(97.8)$ & $9(4.1)$ \\
\hline True bugs (Heteroptera) & 506 & 469 (92.7) & $64(13.6)$ & $6(1.3)$ & $463(98.7)$ & $19(4.1)$ \\
\hline $\begin{array}{l}\text { Vascular plants } \\
\text { (Tracheophyta) }\end{array}$ & ca. 3550 & $\begin{array}{l}1206 \\
(40.0)\end{array}$ & $334(27.7)$ & $9(0.7)$ & $\begin{array}{l}1197 \\
(99.3)\end{array}$ & $67(5.6)$ \\
\hline All species & ca. 13692 & $\begin{array}{l}10432 \\
(76.2)\end{array}$ & $3102(29.7)$ & 304 (2.9) & $\begin{array}{l}10131 \\
(97.1)\end{array}$ & $529(5.2)$ \\
\hline
\end{tabular}


Habitat

Alpine

Aquatic habitats

Mires

Forests

Rock outcrops

Rural biotopes and cultural habitats

Shores
Additional explanation

Alpine heaths and meadows above tree-level

Baltic Sea, lakes and ponds, small ponds, rivers, brooks and streams, rapids, spring complexes

Rich fens, fens, pine mires, spruce mires

Heath forests, herb-rich forests, mountain birch forests

Rock outcrops, including erratic boulders

Seminatural grasslands, wooded pastures and pollard meadows, ditches, arable land, parks, yeards, gardens, roadsides, railway embankments, buildings Shores of the Baltic Sea, lake shores and river banks
Corresponding IUCN habitat

Native grassland

Wetlands

Wetlands (subcategory: bogs, marshes, swamps, fens, peatlands)

Forests

Inland rocky areas

Artificial

Marine/Intertidal and Marine Coastal/Supratidal 
Table 3. The number of taxa in different primary habitats used in the study.

\begin{tabular}{|c|c|c|c|c|c|c|c|c|}
\hline Organism group & $\begin{array}{l}\text { Alpine } \\
\text { heaths } \\
\text { and } \\
\text { meadows }\end{array}$ & $\begin{array}{l}\text { Aquatic } \\
\text { habitats }\end{array}$ & Forests & Mires & $\begin{array}{l}\text { Rock } \\
\text { outcrops }\end{array}$ & $\begin{array}{l}\text { Rural } \\
\text { biotopes } \\
\text { and } \\
\text { cultural } \\
\text { habitats }\end{array}$ & Shores & $\begin{array}{l}\text { All } \\
\text { habitats }\end{array}$ \\
\hline Beetles (Coleoptera) & 889 & 285 & 1559 & 72 & 1 & 33 & 545 & 3384 \\
\hline Birds (Aves) & 36 & 56 & 78 & 20 & 2 & 20 & 25 & 237 \\
\hline $\begin{array}{l}\text { Bryophytes (Bryophyta, } \\
\text { Marchantiophyta and } \\
\text { Anthocerophyta) }\end{array}$ & 81 & 83 & 138 & 123 & 269 & 108 & 71 & 873 \\
\hline Butterflies (Lepidoptera) & 688 & 0 & 1143 & 137 & 27 & 54 & 198 & 2247 \\
\hline $\begin{array}{l}\text { Dragonflies and damselflies } \\
\text { (Odonata) }\end{array}$ & 0 & 46 & 0 & 5 & 0 & 0 & 0 & 51 \\
\hline $\begin{array}{l}\text { Herptiles (Reptilia and } \\
\text { Amphibia) }\end{array}$ & 1 & 2 & 5 & 0 & 0 & 0 & 2 & 10 \\
\hline Lichens (Lichenes) & 57 & 3 & 537 & 17 & 600 & 79 & 99 & 1392 \\
\hline Mammals (Mammalia) & 12 & 7 & 32 & 1 & 0 & 2 & 3 & 57 \\
\hline $\begin{array}{l}\text { Polypores (Aphyllophorales } \\
\text { and Heterobasidiomycetes) }\end{array}$ & 15 & 0 & 198 & 0 & 0 & 0 & 7 & 220 \\
\hline True bugs (Heteroptera) & 191 & 44 & 138 & 9 & 1 & 2 & 78 & 463 \\
\hline $\begin{array}{l}\text { Vascular plants } \\
\text { (Tracheophyta) }\end{array}$ & 346 & 107 & 203 & 129 & 69 & 114 & 229 & 1197 \\
\hline All species & 2316 & 633 & 4031 & 513 & 969 & 412 & 1257 & 10131 \\
\hline
\end{tabular}


580 581 582

Table 4. The RLI in 2000 and 2010 and respective change in different groups of organisms and statistical significance of this change.

\begin{tabular}{lllll}
\hline Group & $\mathrm{RLI} 2000$ & $\mathrm{RLI} 2010$ & Change & $\mathrm{p}$-value \\
\hline Beetles & 0.905 & 0.909 & 0.003 & $<0.001$ \\
Birds & 0.877 & 0.854 & -0.023 & 0.012 \\
Bryophytes & 0.824 & 0.816 & -0.008 & $<0.001$ \\
Butterflies & 0.881 & 0.878 & -0.004 & 0.005 \\
Dragonflies & 0.984 & 0.988 & 0.004 & 0.372 \\
Herptiles & 0.859 & 0.879 & 0.020 & 0.342 \\
Lichens & 0.840 & 0.831 & -0.009 & $<0.001$ \\
Mammals & 0.814 & 0.807 & -0.007 & 0.224 \\
Polypores & 0.846 & 0.849 & 0.004 & 0.144 \\
True bugs & 0.945 & 0.953 & 0.008 & 0.001 \\
Vascular Plants & 0.894 & 0.884 & -0.010 & $<0.001$ \\
\hline
\end{tabular}

583

584

585

586

587

588

589

590

591

592

593

594

595

596

597

598

599

600

601

602

603

604

606

607

608

609

610

611

612

613

614

615

616

617

618

619

620

621

622 
623

\begin{abstract}
classification and IUCN Habitat classification) and the statistical significance, statistically significant changes in different organism groups and habitat combinations; and the likely drivers behind the RLI trends shown in the study with supporting notes and references.

Table 5. The RLI changes between 2000 and 2010 in different primary habitats (Finnish Red Data Book
\end{abstract}

(1) 
Table 6. The changes of RLI for 11 groups of organisms in different primary habitats between 2000 and 2010. Statistically significant combinations are marked with asterisks $\left({ }^{*}=p<0.05,{ }^{* *}=p<0.01,{ }^{* \star *}=p<\right.$ 0.001).

\begin{tabular}{llllllll}
\hline Group & Alpine & Aquatic & Forests & Mires & Rock & Rural & Shores \\
\hline Beetles & 0 & -0.003 & $0.006^{* * *}$ & -0.003 & 0 & $0.004^{*}$ & 0 \\
Birds & -0.04 & -0.028 & -0.002 & $-0.08^{*}$ & 0 & 0 & $-0.048^{*}$ \\
Bryophytes & $-0.02^{* * *}$ & $-0.012^{* *}$ & $-0.007^{* *}$ & $-0.008^{* *}$ & $-0.003^{*}$ & 0 & $-0.02^{* * *}$ \\
Butterflies & -0.015 & 0 & -0.001 & -0.007 & 0.007 & -0.003 & $-0.016^{* *}$ \\
Dragonflies & 0 & 0.004 & 0 & 0 & 0 & 0 & 0 \\
Herptiles & 0 & 0 & 0 & 0 & 0 & 0 & 0.101 \\
Lichens & -0.003 & 0 & $-0.017^{* * *}$ & -0.012 & $-0.004^{* * *}$ & -0.007 & 0 \\
Mammals & 0 & 0 & -0.006 & 0 & 0 & -0.017 & 0 \\
Polypores & 0 & 0 & 0.003 & 0 & 0 & 0.013 & 0 \\
True bugs & 0 & 0.005 & $0.013^{* * *}$ & 0 & 0 & $0.008^{*}$ & 0 \\
Vascular Plants & $-0.019^{* *}$ & $-0.006^{*}$ & -0.006 & $-0.014^{* * *}$ & -0.006 & $-0.009^{* * *}$ & $-0.014^{* * *}$ \\
\hline${ }^{*}$ p $<0.05$ & & & & & & &
\end{tabular}

\section{Appendix 1.}

The species included in the study, their main habitats and the IUCN threat classification in 2000 (backcasted) and 2010.

\section{Appendix 2.}

$R L I$ values for all combinations of taxonomic groups and habitat types (Appendix) are available online. The authors are solely responsible for the content and functionality of these materials. Queries (other than absence of the material) should be directed to the corresponding author. 